\title{
Atrijalna fibrilacija kod bolesnika sa ishemijskom bolešću srca
}

\author{
Milika Ašanin
}

Klinika za kardiologiju, Klinički centa Srbije; Medicinski fakultet, Univerzitet u Beogradu

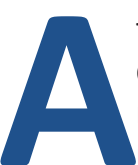
trijalna fibrilacija (AF) je pretkomorski poremećaj srčanog ritma koji se karakteriše nekordinisanom aktivacijom pretkomora, što dovodi do poremećaja njene mehaničke funkcije. AF nastaje u oko 10 do $20 \%$ bolesnika sa AIM. AF u toku AIM je najčešće prolazna i obično nastaje u starijih bolesnika i onih sa srčanom insuficijencijom. Široka primena primarne PCl povezana je sa značajnim smanjenjem incidence AF u toku AIM (7,7\%).1 AF može da kompromituje funkciju leve komore i to putem brzog, iregularnog komorskog odgovora, i gubitkom pretkomorske sistolne funkcije. Bolesnici sa $\mathrm{AF}$ u toku AIM imaju povećan rizik za ishemijski moždani udar u odnosu na one bez $\operatorname{AF}(2,3 \%$ prema $0,6 \%){ }^{1}$

Tabela 1. Preporuke za terapiju AF u akutnom infarktu miokarda 2

\begin{tabular}{|l|c|c|}
\hline & $\begin{array}{c}\text { Klasa } \\
\text { preporuke }\end{array}$ & $\begin{array}{c}\text { Nivo } \\
\text { dokaza }\end{array}$ \\
\hline $\begin{array}{l}\text { Elektrokonverzija se preporučuje } \\
\text { u bolesnika koji su hemodinamski } \\
\text { kompromitovani, sa produženom } \\
\text { ishemijom, ili kod kojih se adekvatna } \\
\text { kontrola srčane ferekvencije ne } \\
\text { može postići lekovima }\end{array}$ & I & C \\
\hline $\begin{array}{l}\text { Intravenski amiodaron se } \\
\text { preporučuje sa ciljem da se uspori } \\
\text { brz komorski odgovor u AF i } \\
\text { poboljša funkcija LK u bolesnika sa } \\
\text { AlM }\end{array}$ & I & C \\
\hline $\begin{array}{l}\text { Intravenski beta blokator i } \\
\text { antagonisti kalcijumskih kanala } \\
\text { nedihidropiridinskog tipa se } \\
\text { preporučuju za usporenje brzog } \\
\text { komorskog odgovora u AF u bolesnika } \\
\text { sa AIM koji nemaju disfunkciju LK, } \\
\text { bronhospazam ili AV blok }\end{array}$ & & \\
\hline $\begin{array}{l}\text { Za bolesnike sa AF i AIM } \\
\text { nefrakcionisani heparin se } \\
\text { preporučuje (aPTT 1,5 do 2 } \\
\text { puta kontrola), osim ako je } \\
\text { kontraindikovan }\end{array}$ & & \\
\hline $\begin{array}{l}\text { Intravesnki digitalis je prihvatljiva } \\
\text { opcija da se uspori brz komorski } \\
\text { odgovor i poboljša fukcija LK u } \\
\text { bolesnika sa AIM i AF koji je praćen } \\
\text { značajnom disfunkcijom LK }\end{array}$ & I \\
\hline
\end{tabular}

Tabela 2. Preporuke za antikoagulantnu terapiju posle implantacije stenta u bolesnika sa AKS i AF

\begin{tabular}{|c|c|c|c|}
\hline $\begin{array}{l}\text { Rizik od } \\
\text { krvarenja }\end{array}$ & $\begin{array}{c}\text { Klinička } \\
\text { slika }\end{array}$ & Stent & Antikoagulantna terapija \\
\hline $\begin{array}{l}\text { Nizak ili } \\
\text { srednji } \\
\text { (npr. HAS- } \\
\text { BLED skor } \\
0-2 \text { ) }\end{array}$ & AKS & $\begin{array}{c}\text { BMS/ } \\
\text { DES }\end{array}$ & $\begin{array}{l}6 \text { meseci: trojna terapija } \\
\text { antagonistima vitamina K (VKA) } \\
\text { (INR 2,0-2,5) + aspirin } \leq 100 \mathrm{mg} / \\
\text { dan + klopidogrel } 75 \mathrm{mg} / \text { dan } \\
\text { Do } 12 \text { meseci: kombinacija VKA } \\
\text { (INR 2,0-2,5) + klopidogrel 75 } \\
\text { mg/dan (ili aspirin } 100 \mathrm{mg} / \text { dan) } \\
\text { Doživotno: samo VKA (INR 2,0-3,0) }\end{array}$ \\
\hline $\begin{array}{l}\text { Visok (npr. } \\
\text { HAS-BLED } \\
\text { skor } \geq 3 \text { ) }\end{array}$ & AKS & BMS & $\begin{array}{l}4 \text { nedelje: trojna terapija sa VKA } \\
\text { (INR 2,0-2,5) + aspirin } \leq 100 \mathrm{mg} / \\
\text { dan }+ \text { klopidogrel } 75 \mathrm{mg} / \text { dan } \\
\text { Do } 12 \text { meseci: kombinacija VKA } \\
\text { (INR } 2,0-2,5)+ \text { klopidogrel } 75 \\
\text { mg/dan (ili aspirin } 100 \mathrm{mg} / \text { dan) } \\
\text { Doživotno: samo VKA (INR 2,0-3,0) }\end{array}$ \\
\hline
\end{tabular}

Tabela 3. Kliničke karakteristike koje sačinjavaju HAS-BLED skor rizika za krvarenje ${ }^{3}$

\begin{tabular}{|c|l|c|}
\hline Slovo & Klinička karakteristika & Broj poena \\
\hline H & Hipertenzija & 1 \\
\hline A & $\begin{array}{l}\text { Abnormalna funkcija bubrega ili } \\
\text { jetre (1 poen svaka) }\end{array}$ & 1 ili 2 \\
\hline S & Moždani udar & 1 \\
\hline B & $\begin{array}{l}\text { Prethodno krvarenje i/ili } \\
\text { predispozicija za krvarenje }\end{array}$ & 1 \\
\hline L & Promenljivi INR & 1 \\
\hline E & Stariji (npr >65 godina) & 1 \\
\hline D & Lekovi* ili alkohol (1 poen svaki) & 1 ili 2 \\
\hline & & $\begin{array}{c}\text { Maksimum } \\
9 \text { poena }\end{array}$ \\
\hline
\end{tabular}

*antitrombocitna terapija, nesteroidni antiinflamatorni lekovi

Pre uvođenja antikoagulantne terapije potrebno je izvršiti procenu rizika od krvarenja. Prevalenca velikih krvarenja sa trojnom terapijom (VKA, aspirin i klopidogrel) je 2,6-4,6\% u toku 30 dana, a povećava se na 7,410,3\% u toku 12 meseci. ${ }^{3}$ Tako da trojna terapija izgleda ima prihvatljiv odnos rizika i koristi ako se primenjuje kratko (npr. 4 nedelje), a rizik od krvarenja je u tom slučaju mali. Za procenu rizika od krvarenja kod bolesnika sa AF koristi se novi jednostavan HAS-BLED skor, pri če- 
mu skor $\geq 3$ ukazuje na „visok rizik" pa je za te pacijente potreban poseban oprez i redovne kontrole posle započinjanja antitrombotične terapije, bilo sa VKA ili aspirinom.

\section{Literatura:}

1. Kinjo K., Sato H., Ohnishi Y.,et al. Prognostic significance of atrial fibrillation/atrial flutter in patients with acute myocardial in farction treated with percutaneous coronary intervention. Am J Cardiol 2003; 92 (10): 1150-4.
2. Fuster V., Ryden LE, Cannom DS, et al. ACC/AHA/ESC 2006 guidelines for the management of patients with atrial fibrillation-executive summary: a report of the American College of Cardiology/ American Heart Association Task Force on Practice Guidelines and the European Society of Cardiology Committee for Practice Guidelines (Writing Committee to Revise the 2001 Guidelines for the Management of Patients With Atrial Fibrillation). J Am Coll Cardiol 2006; 48 (4): 854-906.

3. Camm AJ, Kirchhof P, Lip GY, et al. Guidelines for the management of atrial fibrillation: the Task Force for the Management of Atrial Fibrillation of the European Society of Cardiology (ESC). Eur Heart J., 2010; 31 (19): 2369-429. 